\title{
$\mathrm{RCP}$ 시나리오를 고려한 극치통계분석 및 빈도해석
}

\author{
김덕환 · 김연수 · 홍승진 · Ly Sidoeun · 정영훈* · 김형수+ \\ 인하대학교 토목공학과 \\ * 국립강원대학교 지역건설과
}

\section{The ETCCDI and Frequency Analysis using RCP Scenarios}

\author{
Duck Hwan Kim · Yon Soo Kim · Seung Jin Hong · Sidoeun Ly • \\ Younghun Jung* · Hung Soo $\mathrm{Kim}^{+}$ \\ Department of Civil Engineering, Inha university, Korea \\ * Regional infrastructure engineering, Kangwon national university, Korea
}

\section{요 약}

\begin{abstract}
본 연구에서는 기상청 산하 30 년 이상의 관측치를 갖고 있는 기상관측소 58 개 지점을 대상으로, 과거 관측자료 및 대표 농도경로(RCP) 시나리오에 의한 강수량 자료를 이용하여 극치통계분석 및 확률강수량을 산정하였다. 기후변화 시나리오 자료의 편의를 제거하기 위하여 분위사상법(Quantile Mapping) 및 이상치 검정을 실시하였다. 이를 통해 보정된 시나리오 값을 이용하여 ETCCDI 극한지수 중에서 강수관련 지수를 이용한 극치통계분석을 실시하였고, 빈도해석을 통한 미래 목 표기간별 확률강수량의 변화율을 살펴보았다. 미래 기후변화에 따른 2090년대에는 한반도 전체에서 비가 오지 않는 날은 증가하였으며, 하루에 $80 \mathrm{~mm}$ 이상 비가 오는 집중호우가 발생하는 기간 또한 3 7\% 증가하는 경향을 나타낼 것으로 분 석되었다. 즉, 미래의 강수 특성은 현재에 비해서 가뭄 및 집중호우 또는 폭우와 같은 형태로 발생할 확률이 증가한다는 의미로 해석할 수 있다. 기후변화에 따른 미래 확률강수량은 지속시간 $24 \mathrm{hr}$ 의 경우 현재에 대비하여 80 년 빈도는 $17.7 \%$, 100 년 빈도는 $18.2 \%, 200$ 년 빈도는 $19.6 \%$ 이상 증가 하는 것으로 분석되었다. 미래 기후변화로 인한 강수량의 증가와 도 시화에 따른 유출특성 변화로 자연재해 발생 및 피해는 더욱 증가할 것으로 예측된다. 이에, 본 연구에서 제시한 극치통 계분석 및 확률강수량 자료는 미래 홍수 안전도 및 방재시설물 설계기준을 수립하는데 기초자료로 활용할 수 있을 것으 로 기대된다.
\end{abstract}

핵심용어 : 기후변화, 극치통계분석, 확률강수량, 대표농도경로(RCP) 시나리오

\section{Abstract}

In this study we estimated ETCCDI and frequency based precipitation using observed precipitation and precipitation from Representative Concentration Pathway(RCP) scenarios for 58 weather stations which have the recorded data more than 30 years. We tried to eliminate the bias by Quantile Mapping and tested for outliers of simulated data under climate change scenario. Then we estimated ETCCDI related to precipitation and frequency based precipitation for the future. In addition to this study examined the changes of frequency based precipitation for the future target periods. According to the result, dry days will be increased in Korean Peninsula in the 2090s. Also it showed that the number of heavy precipitation day more than $80 \mathrm{~mm} /$ day tends to be increased in $3 \sim 7 \%$ in the future. The precipitation of 24-hour duration under climate change will be increased by $17.7 \%$ for 80 -year frequency, $18.2 \%$ for 100 -year frequency and $19.6 \%$ for 200 -year frequency in 2090s. In the 21st century, the damage caused by natural disasters is expected to be increased due to increase of precipitation and the change of runoff characteristics under climate change. Therefore, the proposed ETCCDI and precipitation frequency under climate change are expected to be used for the future natural disaster plan.

Keywords : Climate Change, ETCCDI, Frequency based precipitation, RCP Scenarios

\footnotetext{
+ Corresponding author : sookim@inha.ac.kr
} 


\section{1. 서 론}

지구온난화로 인한 기후변화로 한반도 및 전 세계적 으로 집중호우 및 돌발홍수, 극한가뭄 등 자연재해로 인 한 피해가 증가하고 있다. IPCC (Intergovernmental Panel on Climate Change, IPCC) 5 차 보고서(2013)는 현재와 같은 증가추세로 온실가스가 발생할 경우 지구 평균 기 온은 $3.7^{\circ} \mathrm{C}$, 해수면은 $63 \mathrm{~cm}$ 증가할 것이라고 전망하였 다.

최근에 발생하고 있는 기후변화는 극한 온도, 바람, 강설, 강수, 해수면 상승과 같이 인간생활에 직간접적으 로 영향을 미치는 자연현상의 변화를 초래하고 있다. 이 러한 자연현상의 변화는 국가와 국민들에게 막대한 물 적 정신적 피해를 입히게 되어 국가적 차원에서 기후변 화에 적응하기 위한 대안 마련이 필요하다. IPCC 4차 보고서(2007)에서는 인간의 활동으로 인한 지구온난화의 가능성은 $90 \%$ 정도로 밝혔었지만, 이번 보고서에서는 $95 \%$ 이상이라고 밝혔다. 한반도와 같은 경우 현재와 같 은 온실가스 배출추세를 유지할 경우 21 세기 중반에는 강수량이 약 $15.6 \%$ 증가하며, 해수면은 $27 \mathrm{~cm}$ 상승할 것으로 전망 하고 있다. 이에 미래 확률강수량은 증가할 것으로 예측되며 폭우 및 태풍으로 인한 피해도 증가할 것이라고 판단된다.

같은 양의 강수가 발생하더라도 산업화에 따른 도시 의 불 투수면적의 증가는, 홍수나 침수에 의한 피해를 심화시킬 것으로 예상된다. 기후변화에 관한 정부간 협 의체가 2012년에 발표한 보고서에 의하면 극한기온이나 호우의 빈도가 증가할 가능성이 높다고 분석하였다. 우 리나라도 지난 20세기 (1912 2010년) 동안 지구온난화와 도시화의 영향으로 기온이 $0.18^{\circ} \mathrm{C} / 10$ 년 상승하였으며, 동 일한 기간에서 강수량은 $21 \mathrm{~mm} / 10$ 년 으로 증가하여 이 미 우리나라도 지구온난화로 인한 기후변화가 시작되었 다는 것을 알 수 있다.

기후변화를 고려한 미래강수량 변동성 예측 및 빈도 해석과 관련한 연구는 국내·외 많은 연구들이 수행되어 왔는데 국외의 경우 Odena and Prudhomme (2002)는 미 래의 강우·유출 모델에 적용하기 위한 자료를 구축하고, 홍수량 빈도해석을 실시하였으며, Fowler et al. (2005) 은 2005년에 영국의 Hadley 센터에서 개발한 HadRM2, $\mathrm{HadRM} 3 \mathrm{H}$ 를 이용하여 지역빈도해석 및 Grid Box Analysis (GBA)를 통한 평가 및 확률강우량의 변화를 분 석하였는데, 영국내의 50 년 이상의 극한 강우에 대하여 $\mathrm{HadRM} 3 \mathrm{H}$ 모형을 이용한 극한강우 재현의 적용성 평가 결과는 만족할만한 결과를 보여주었다. Villarini et al. (2013)은 CMIP5 모델을 이용하여 새로운 기후변화 시나 리오인 대표농도경로 RCP 시나리오를 이용하여 미래로 갈수록 폭우가 미국 중부지역에 미치는 영향을 평가를
하였다. Otieno and Anyah (2013)는 대표농도경로 RCP 시나리오를 이용하여 아프리카 대륙의 북동부의 온도 및 강수량의 변화를 RCP $4.5,8.5$ 별로 계절별 분석을 실시하는 등 새로운 시나리오를 이용하여 많은 연구가 활발히 이루어지고 있다.

국내에서도 Kyoung (2010)은 기후변화가 표준강수 지 수 및 확률강수량에 미치는 영향을 평가하기 위하여 $\mathrm{KMA} \mathrm{RCM}$ 모형을 대상으로 K-NN기법, 카오스 시간분 해 등을 적용하여, 기후변화에 따른 확률강수량 변화를 분석하였다. Lee (2011)는 기후변화를 고려하여 예상홍 수피해액을 산정하기 위하여 연 최대 홍수량을 산정하 고, HEC-FDA에서의 불확실성 분석 방법을 통해 불확실 성을 고려한 확률강우량을 재산정후, 다차원홍수피해산 정방법(MD-FDA)을 이용하여 예상홍수 피해액을 산정하 였다. Kim (2011)은 CNCM3 GCM 모형을 사용하여 기 후변화로 인하여 수자원 및 수생태에 미치는 영향을 정 량적으로 평가를 하였다. 신 시나리오인 RCP 시나리오 를 이용한 연구로는 Sung et al. (2012)은 대표농도경로 RCP $4.5,8,5$ 를 이용하여 21 세기 말 강수량을 전망하기 위하여 GEV 분포를 이용하여 분석을 하였고, Kim et al. (2012)은 신 시나리오를 이용하여 남한지역의 가뭄의 변 화를 예측하기도 하였다. Hong et al. (2012)은 기후변화 변동성지수를 산정하여 지역별 수자원 특성 분석을 실 시하였으며, Kim et al. (2012)은 SWMM 모형을 이용하 여 기후변화가 도시배수의 미치는 영향을 분석하기도 하였다.

기후변화 영향을 고려한 국내·외 다양한 연구들이 이 루어지고 있는 가운데, 본 연구에서는 새로운 AR5 대표 농도경로 시나리오를 이용하여 기후변화의 영향을 수문 학적 측면에서 정량적으로 검토하기 위하여 극치통계분 석과 지점 및 지역빈도해석을 실시하여 새로운 시나리 오에 대처하는데 있어서 기본 정보를 제공하고자 한다.

\section{2. 대표농도경로(RCP) 시나리오}

\section{1 기후변화의 정의 및 대표농도경로 시나리오}

기후변화란 기후의 상태변화가 기후 특성의 평균이나 변동성의 변화를 통해 확인되고 그 변화가 일반적으로 10 년 이상 지속되는 것을 말한다. 기후변화는 자연적 내 부과정, 즉 외부강제력 때문이거나 대기 조성 또는 토지 사용의 지속적인 인위적 변화 때문일 수 있기에, 대기 조성을 변경시키는 인간 활동으로 인한 기후변화와 자 연적 원인 때문일 수 있는 기후변동성을 구분하고 있다.

IPCC 5 차 보고서(2013) 에서는 인간 활동이 대기에 미치는 복사량으로 온실가스 농도를 정하였는데, 하나의 대표적인 복사강제력에 대해 사화·경제 시나리오는 여러 가지가 될 수 있다는 의미에서 대표(Representative)라는 
Table 1. RCP Scenarios and SRES Scenarios

\begin{tabular}{c|c|c|c|c|c|c|c}
\hline \multirow{2}{*}{ Scenarios } & \multicolumn{4}{|c|}{ RCP Scenarios } & \multicolumn{3}{c}{ SRES Scenarios } \\
\cline { 2 - 8 } & 2.6 & 4.5 & 6.0 & 8.5 & B1 & A1B & A2 \\
\hline \hline$C O_{2} \quad(\mathrm{ppm})$ & 420 & 540 & 670 & 940 & 550 & 720 & 830 \\
\hline
\end{tabular}

표현을 사용하였다. 온실가스 배출 시나리오의 시간에 따른 변화를 강조하기 위해 경로(Pathways)라는 의미를 포함하고 있다.

$\mathrm{RCP}$ 시나리오는 최근 온실가스 농도 변화경향을 반 영하였고 최근 예측 모델에 맞게 해상도도 기존의 시나 리오보다 더 상세해 졌다. 4차 평가보고서에서 제시되었 던 SRES 시나리오와 $\mathrm{RCP}$ 시나리오의 $\mathrm{CO}_{2}$ 기준 $\mathrm{ppm}$ 의 변화는 Table 1에서 제시하였다.

$\mathrm{RCP}$ 시나리오의 경우 기후변화 대응정책과 연계하여 선정되었으며, SRES 시나리오의 경우 미래 사회구조를 중심으로 선정되었다. 시나리오별 농도의 차이는 $\mathrm{RCP}$ 2.6 일 경우 인간 활동에 의한 영향을 지구 스스로가 회 복 가능한 경우를 나타내며, RCP 4.5일 경우 온실가스 저감 정책이 상당히 실현되는 경우, $\mathrm{RCP} 6.0$ 의 경우 온 실가스 저감 정책이 어느 정도 실현되는 경우를 나타낸 다. RCP 8.5 의 경우는 현재 추세대로 저감 없이 온실가 스가 배출되는 경우를 의미한다.

\section{2 기후모형의 선정}

국립기상연구소는 2009년부터 영국 기상청 해들리센 터와 협력을 통해 지구시스템모델을 도입하여 2012년에 는 RCP 시나리오 4종(2.6/4.5/6.0/8.5)에 대한 기후변화를 전망하였고 이에 대한 분석 결과를 "기후변화 시나리오 보고서 2012”에 발표하였다. 또한, 지역 기후변화모델을 이용하여 우리나라 지형 영향 등을 보다 현실에 가깝게 반영하고 평균적인 기후 변화뿐만 아니라 극한 기온과 폭우 등에 대해도 평가하였으며, 국내 기후변화 영향, 취약성 평가 및 적응 대책 수립 등의 기후변화 대응을 위해 제공되고 있다.

본 연구에서는 기후변화 시나리오 산출에 이용되는 영국 기상청 해들리센터 지역기후모델인 HadGEM3-RA 를 기반으로 기상청에서 제공하고 있는 한반도 $(12.5 \mathrm{~km})$ 기후변화 시나리오를 이용하여 미래 기후변화에 따른 확률강수량을 산정하였다. Table 2 는 해들리 모형에 관 한 간략한 설명을 나타내었다.

Table 2. Comparison of Global Climate Model and Regional Climate Model

\begin{tabular}{c|c|c}
\hline & Global Projection & Regional Projection \\
\hline \hline Period (years) & $1850 \sim 2300$ & $1950 \sim 2100$ \\
\hline Scenario & RCP $4.5 / 8.5 / 2.6 / 6.0$ & RCP $4.5 / 8.5 / 2.6 / 6.0$ \\
\hline Model & HadGEM2-AO & HadGEM3-RA \\
\hline Grid spacing & $\sim 135 \mathrm{~km}\left(1.875^{\circ} \times 1.25^{\circ}\right)$ & $\sim 12.5 / 50 \mathrm{~km}\left(0.11 / 0.44^{\circ}\right)$ \\
\hline
\end{tabular}

\section{3. 강수자료의 편의보정 및 이상치 검정}

\section{1 분위사상법(Quantile Mapping)을 이용한 편의 보정}

분위사상법(Quantile Mapping)은 관측값과 시나리오 모의값이 함께 존재하는 과거 기간에서, 관측값과 시나 리오 모의값의 누적확률분포 값을 이용하여 편의가 발 생하여 과소추정되는 시나리오 모의값의 확률분포를 관 측값의 확률분포에 사상시키는 방법이다.

기후변화모형으로부터 축소된 결과들은 실제 관측값 과 일정정도 편의를 보이게 된다. 이러한 편의를 보정하 기 위하여 가장 일반적으로 사용되는 방법이 Panofsy and Brire (1963)에서 제시한 분위사상법이다. 분위사상
법은 유출량을 보정하는 방법으로 주로 사용되었으며, 기후변화 분야와 관련해서는 국내에서도 $\mathrm{Kim}$ et al. (2008), Kyoung et al. (2009)에서 적용된바 있다. 이러한 분위사상법의 일반적인 절차는 Fig. 1 과 같으며, 다음 식 (1)로 표현된다.

$$
Z_{j}=F_{o j}^{-1}\left(F_{s j}\left(\widehat{Y}_{j}\right)\right)
$$

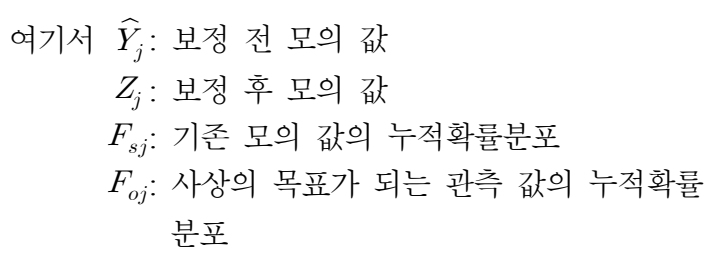




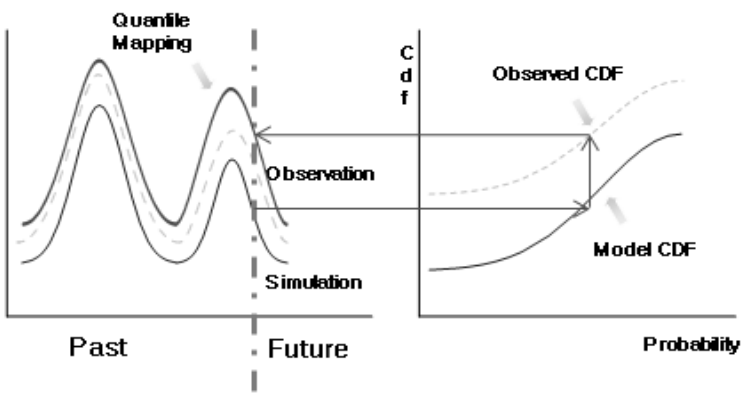

Fig. 1. The Concept of Quantile Mapping

\section{2 이상치 검정}

자료의 이상치(outlier)란 어떤 집단으로부터 추출한 무 작위(random) 표본에서 다른 값들에 비해 비정상적으로 떨어져 있는 극단적으로 크거나 작은 값을 말한다. 자료 에서 하나 또는 그 이상의 이상치가 존재하면, 계산된 통계량은 그에 의해 큰 영향을 받아 편중된 결과를 가져 올 수 있다. 이상치 분석방법으로는 그래프분석, 수학적 인 방법, Dixon의 검정, Grubb의 검정, Barnett \& Lewis 검정 등이 있다. 본 연구에서는 수학적인 방법인 상자그 림(Box Plot)방법을 사용하여 이상치를 검정하였다.

상자그림은 제 3 사분위수 $\left(Q_{3}\right)$ 와 제 1 사분위수 $\left(Q_{1}\right)$ 사이 에 상자를 그리고, 상자 가운데 중앙값의 위치를 나타내 기 위해 보통 실선을 그린다. 다음의 경계(fence)들은 분 포의 꼬리에 있는 이상치를 확인하는 데에 사용된다.

1. 내부 하한(lower inner fence, LIF) : $Q_{1}-1.5 \times I Q R$

2. 내부 상한(upper inner fence, UIF) : $Q_{3}+1.5 \times I Q R$

3. 외부 하한(lower outer fence, $\mathrm{LOF}): Q_{1}-3 \times I Q R$

4. 외부 상한(upper outer fence, $\mathrm{UOF}): Q_{3}-3 \times I Q R$

여기에서 $I Q R$ 은 interquartile range로서 $Q_{3}-Q_{1}$ 으로 정의된다. 관측치가 내부 하한 또는 내부 상한을 넘고, 외부 하한 또는 외부 상한 내에 있는 값은 약한 또는 잠재적인 이상치(mild 또는 potential outlier)라고 하고, 외부 하한 및 상한을 넘는 값은 극단적인 또는 문제 있 는 이상치(extreme 또는 problematic outlier)로 판별하게 된다.

\section{ETCCDI 극한지수와 빈도해석}

\subsection{ETCCDI 극한지수}

시계열자료를 분석할 때 극치 변화를 평가하는 것은 아주 중요하며, 평균적인 측면에서 강수량 및 온도의 증 가로 인하여 홍수 발생 및 가뭄 발생의 증가로 생각할 수도 있다. 하지만, 치수 및 재해 분야의 측면에서 볼
때, 평균값보다는 재해에 직접적인 영향을 미치는 극치 값이 더욱 중요하다고 판단된다. 기후변화로 인한 미래 확률강수량을 합리적으로 산정하기 위해서는 통계학적 으로 강수의 분포와 극치 사상의 경향성 분석이 선행되 어야 한다. 세계기상기구(WMO, World Meteorological Organization)에서는 일 단위의 시계열 자료에 대한 극치 사상의 정량화에 대한 중요성을 인식하고 극치값의 분 석과 관련한 가이드라인“Guidelines on Analysis of extremes in a changing climate in support of informed decisions for adaptation(WMO, 2009)"을 제시하였다.

$\mathrm{WMO}$ 에서 제시하고 있는 극한지수(ETCCDI, Expert Team on Climate Change Detection and Indices)는 관측된 자료의 극치 기상 및 기후의 변화를 파악할 수 있도록 극치지수를 정의하였고, 온도관련 극한지수 16 개와 강수 관련 극한지수 11 개로 총 27 개의 극한지수로 구성되어 있다. 본 연구에서는 강수관련 11 개 극한 지수 중 우리 나라에 적용 가능한 7 개 지수를 선정 및 검토하였다.

\section{(1) RX1day : Max 1-day precipitation amount}

$R R_{i j}$ 는 $j$ 기간 동안 $i$ 일의 총 강수량이며, $j$ 기간 내 에 1 일 총 강수량의 최대값을 산정함으로써 1 일 최대 강수량을 산정한다.

$$
R X 1 d a y_{j}=\max \left(R R_{i j}\right)
$$

\section{(2) $R X 5$ day : Max 5-day precipitation amount}

$R R_{i j}$ 는 $j$ 기간 동안 $i$ 일의 연속 5 일 총 강수량이며, $j$ 기간 내에 5 일 총 강수량의 최대 값을 산정함으로써 5 일 최대 강수량을 산정한다.

$$
R X 5 d_{a y}=\max \left(R R_{i j}\right)
$$

\section{(3) $S D \Pi$ : Simple daily intensity index}

$R R_{w j}$ 는 $j$ 기간 동안 습윤일 $w(R R \geq 1 \mathrm{~mm})$ 의 일 총 강수량이며, $W$ 는 $j$ 기간 내에 습윤 기간일수이다.

$$
S D \Pi_{j}=\frac{\sum_{w=1}^{W} R R_{w j}}{W}
$$

\section{(4) $R 20$ : Number of very heavy precipitation days}

$$
R R_{i j} \text { 는 } j \text { 기간 동안 } i \text { 일의 일총강수량이며, } R R_{i j} \text { 가 }
$$
$20 \mathrm{~mm}$ 이상 발생하는 일수로 나타낸다.

$$
R R_{i j} \geq 20 \mathrm{~mm}
$$




\section{(5) Rnn : Number of days above $\mathbf{n n} m m$}

$R R_{i j}$ 는 $j$ 기간 동안 $i$ 일의 일총강수량이며, $R R_{i j}$ 가 $\mathrm{nn} m \mathrm{~m}$ 이상(사용자 정의) 발생하는 일수로 나타낸다.

$$
R R_{i j} \geq n n m m
$$

\section{(6) $C D D$ : Consecutive dry days}

$R R_{i j}$ 는 $j$ 기간 동안 $i$ 일의 총강수량이며, $R R_{i j}$ 가 1 $\mathrm{mm}$ 미만일 때 연속적으로 발생하는 날의 수이다.

$$
R R_{i j} \leq 1 \mathrm{~mm}
$$

\section{(7) $C W D:$ Consecutive wet days}

$R R_{i j}$ 는 $j$ 기간 동안 $i$ 일의 총강수량이며, $R R_{i j}$ 가 1 $\mathrm{mm}$ 이상일 때 연속적으로 발생하는 날의 수이다.

$$
R R_{i j} \geq 1 \mathrm{~mm}
$$

\section{2 지점 빈도해석}

빈도해석은 특정 크기의 강수나 홍수 혹은 갈수의 발 생빈도를 확률적으로 예측하는 방법이다. 관측지점의 자 료에 국한 되는 경우 지점 빈도해석(Point Frequency Analysis)이라하며, 어떠한 유역 내의 여러 관측지점의 점 빈도해석 결과를 사용하여 지역을 일관하는 수문량 의 빈도특성을 나타내는 경우를 지역빈도해석(Regional Frequency Analysis)라 한다.

빈도해석을 실시하기에 앞서 대상 자료를 도시하여 그 경향을 파악함으로써 자료가 가지는 기본특성을 파 악할 수 있다. 빈도해석을 위해서는 자료가 서로 독립 (independent)이어야 하며, 자료의 독립성을 평가하기위해 무작위성(randomness)검토를 진행하는 것이 중요하다. 자 료의 양이 제한적일 때 전체 모집단의 확률분포형을 추 정하려면 기본적으로 무작위 변수(random variable)의 특 성을 나타내어야 한다. 이러한 무작위성 검정을 위한 방법 으로는 Run test, Anderson의 Correlogram Test, Spearman 의 Rank Correlation Coefficient Test, Turning Point Test 등이 있다. 수문자료 해석에 사용되는 일반적인 확률분 포형으로 Gamma 분포, GEV (General Extreme Value)분 포, Gumbel 분포, log-Gumbel 분포, lognormal 분포, log-Pearson type III 분포, Weibull 분포, Wakeby 분포가 있다. 대상자료가 추출된 모집단의 특성을 반영하는 매 개변수를 추정한 후, 적합도 검정을 통하여 추정된 매개 변수와 확률분포형이 적합한지를 판단하여 빈도해석을 진행하게 된다. 확률분포형의 매개변수를 추정하는 방법 은 일반적으로 모멘트법(method of mements, MOM), 최 우도법(method of maximum likelihood, ML), 확률가중모 멘트법(method of probability weighted moments, PWM) 등이 주로 빈도해석 시 사용된다.

\section{5. 기후변화를 고려한 강수량변화 영향평가}

\section{1 대상지점 및 목표기간}

기상청 산하 69 개 기상관측소 중 관측 기상자료에 대 한 통계적 유의성 확보를 위해 30년 이상의 자료를 보 유하고 있는 58 개 지점을 선정하였다.

본 연구에서는 기후변화의 영향을 단기, 중기, 장기로 예측하기 위하여 분석기간을 Table. 3과 같이 1971 2005 년(Target I ), 2006 2040년(Target II), 2041 2070년(Target III), 2071 2100(TargetIV)로 구분하여 분석을 실시하였다.

Table 3. Target periods

\begin{tabular}{c|c}
\hline Division & Period \\
\hline \hline Target I & $-1971 \sim 2005$ years (Observation, Reference) \\
\hline Target II & $-2006 \sim 2040$ years (Projection period) \\
\hline Target III & $-2041 \sim 2070$ years (Projection period) \\
\hline Target IV & $-2071 \sim 2100$ years (Projection period) \\
\hline
\end{tabular}

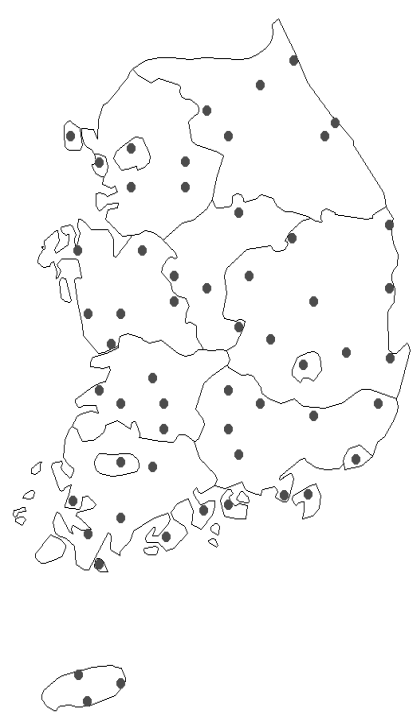

Fig. 2. Weather stations

\section{2 시나리오 자료의 편의보정 및 이상치 검정}

관측강수량을 기준으로 과거기후 모의 확률강수량과 $\mathrm{RCP} 4.5,8.5$ 시나리오를 월 별 일 자료로 분리하여 편 의보정을 실시하였다.

이상치 검정에서는 그래프분석, Dixon, Grubb, Barnet $\&$ Lewis, 상자그림 방법에 대한 검토를 하였다. 그래프 분석방법의 경우 개인마다 주관적인 판단이 들어가므로 제외시켰으며, Dixon 방법의 경우 관측치가 25지점을 초 과할 경우 사용할 수가 없다. Grubb 방법은 정규분포일 경우 사용이 가능하며, Barnett \& Lewis의 검정은 관측 치의 개수에 따른 임계치의 값을 주어진 표에서 선택하 여야 하기에, 주어진 관측치의 개수와 일치하지 않을 경 우에, 임계치를 역으로 계산하여 적용시켜야 한다는 단 
점이 있다.

따라서 본 연구에서는 가장 수학적이며, 널리 사용되는 방법 중의 하나인 상자그림 방법을 사용하여 이상치를 제 거하였다. 이상치의 종류는 잠재 이상치(mild or potential outlier)와 극단적인 이상치(extreme or problematic) 중에서 잠재 이상치를 사용하여 계산하였다.

\section{3 강우관련 ETCCDI 극한지수 산정}

강수관련 ETCCDI 극한지수 중에서, RX1day, RX5day, R20, R80, SDII, SDD, SWD를 이용하여, 1971 2005년도 까지 관측강수량에 대한 극치 통계분석을 수해하여 Fig.
3 Fig. 9와 같이 지수를 산정하였다.

Table 4와 Fig. 3 Fig. 9 에는 우리나라 주요도시를 대상으로 분석을 한 결과, 대부분의 지수들이 상승하는 경향을 나타내었다. 특히, 집중호우의 증가를 의미하는 $R 80$ 같은 경우 전 지역에서 상승하는 경향을 나타냈으 며, 강수가 $1 \mathrm{~mm}$ 이하로 발생하는 연속적인 날인 $C D D$ 값은 두 곳을 제외하고 모두 증가하였다. 강우가 $1 \mathrm{~mm}$ 이상으로 발생하는 연속적인 날인 $C W D$ 값도 증가하는 경향을 나타내었다. 극치분석을 통한 한반도의 강수량 특성을 살펴보면 연속 무강수 일수는 길어지고, 연속 강수 일수도 늘어나는 것을 확인할 수 있다.

Table 4. ETCCDI for station in Major Cities, Korea

\begin{tabular}{c|l|l|l|l|l|c|c}
\hline Station & $R X 1$ day & $R X 5$ day & $S D \Pi$ & $R 20$ & $R 80$ & $C D D$ & $C W D$ \\
\hline \hline Seoul & 1.011 & 4.737 & 0.173 & 0.091 & 0.073 & 0.063 \\
\hline Incheon & 0.887 & 2.842 & 0.122 & 0.043 & 0.061 & 0.152 & 0.030 \\
\hline Daejeon & 2.019 & 3.417 & 0.157 & 0.078 & 0.052 & 0.064 & 0.017 \\
\hline Daegu & 0.459 & 1.643 & 0.075 & 0.051 & 0.024 & -0.044 & 0.052 \\
\hline Ulsan & 0.472 & 1.297 & 0.065 & 0.093 & 0.032 & 0.057 & 0.029 \\
\hline Gwangju & 0.312 & 0.350 & 0.040 & 0.028 & 0.014 & 0.093 & 0.064 \\
\hline Busan & -0.503 & 0.600 & 0.132 & 0.104 & 0.064 & 0.081 \\
\hline Jejudo & 0.858 & 0.929 & 0.109 & -0.010 & 0.031 & 0.116 & 0.011 \\
\hline Average & 0.689 & 1.977 & 0.109 & 0.060 & 0.044 & 0.058 \\
\hline
\end{tabular}
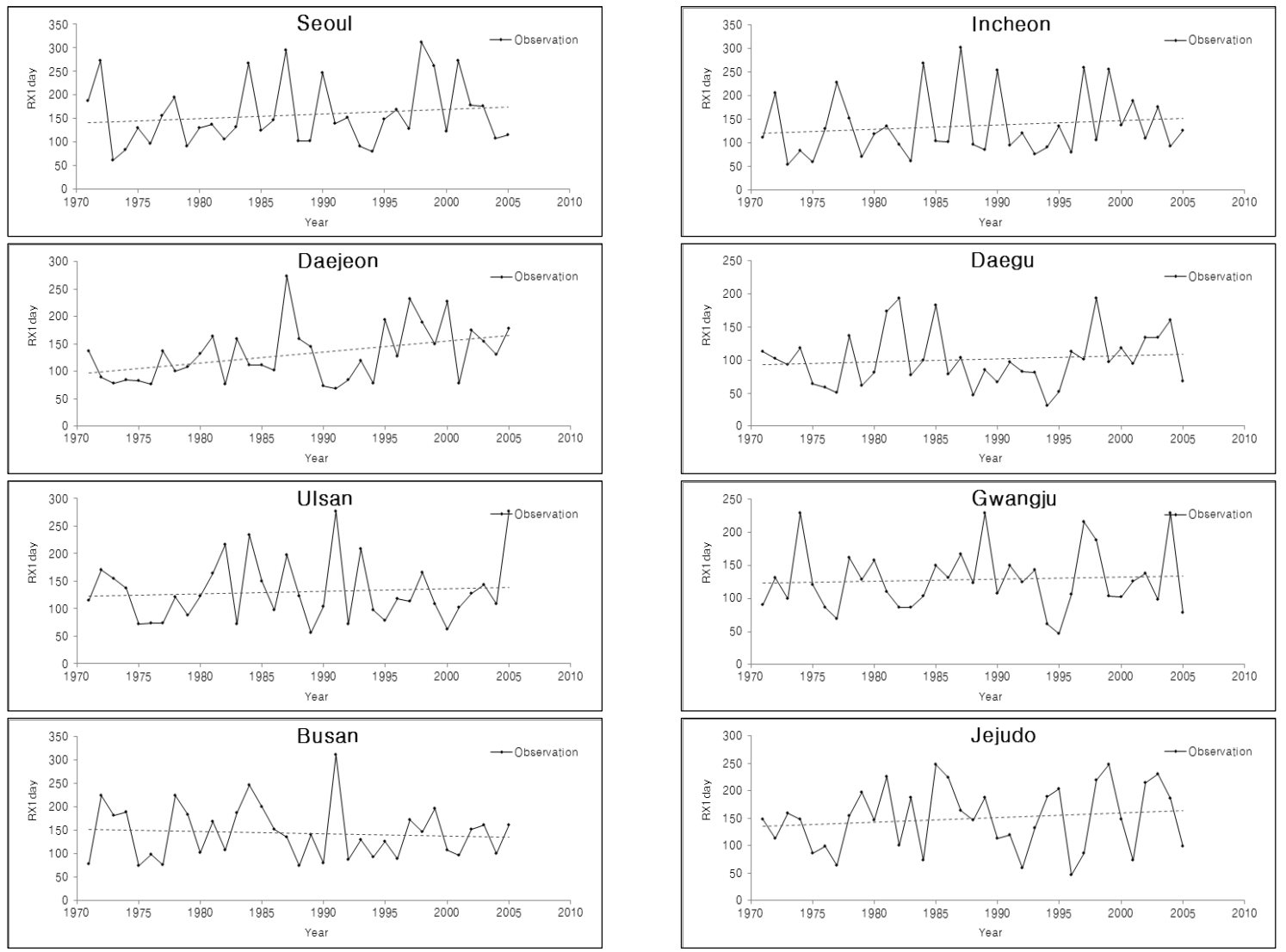

Fig. 3. 1-day max precipitation ( $R X 1$ day $)$ 

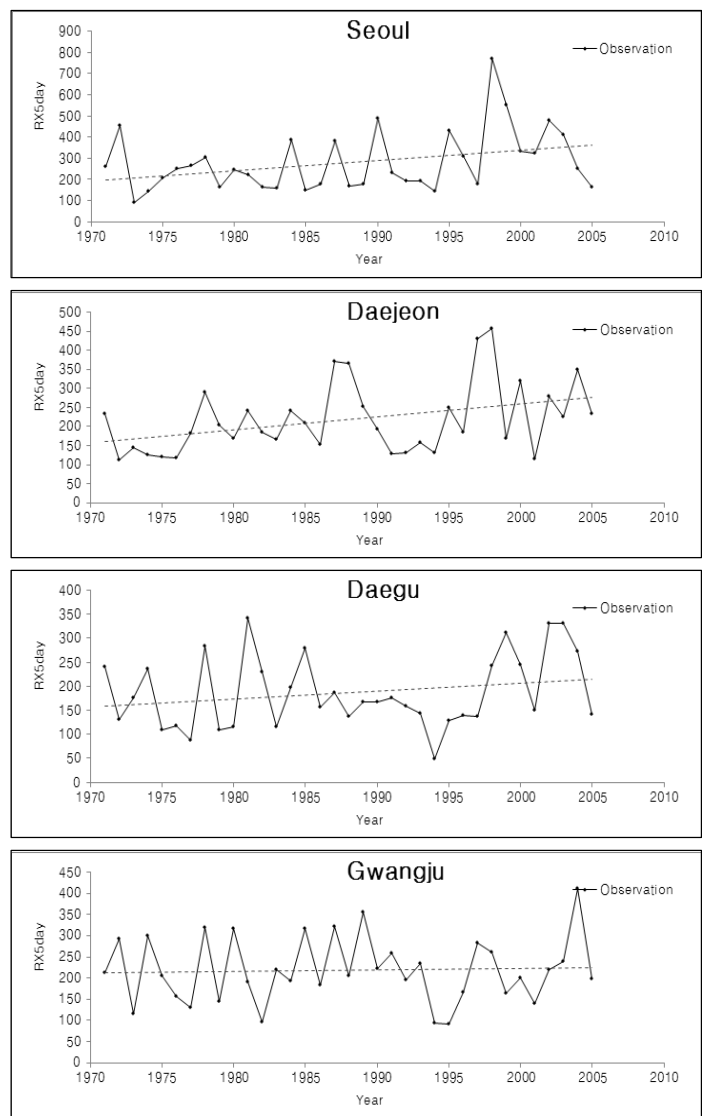
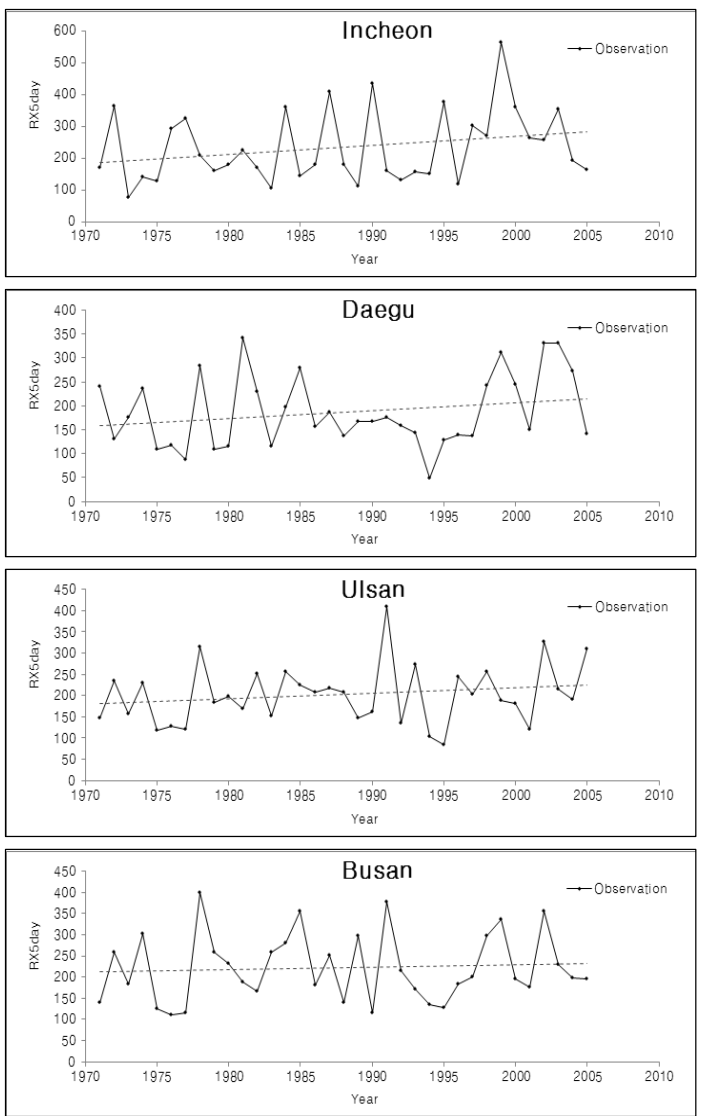

Fig. 4. 5-day max precipitation ( $R X 5$ day $)$
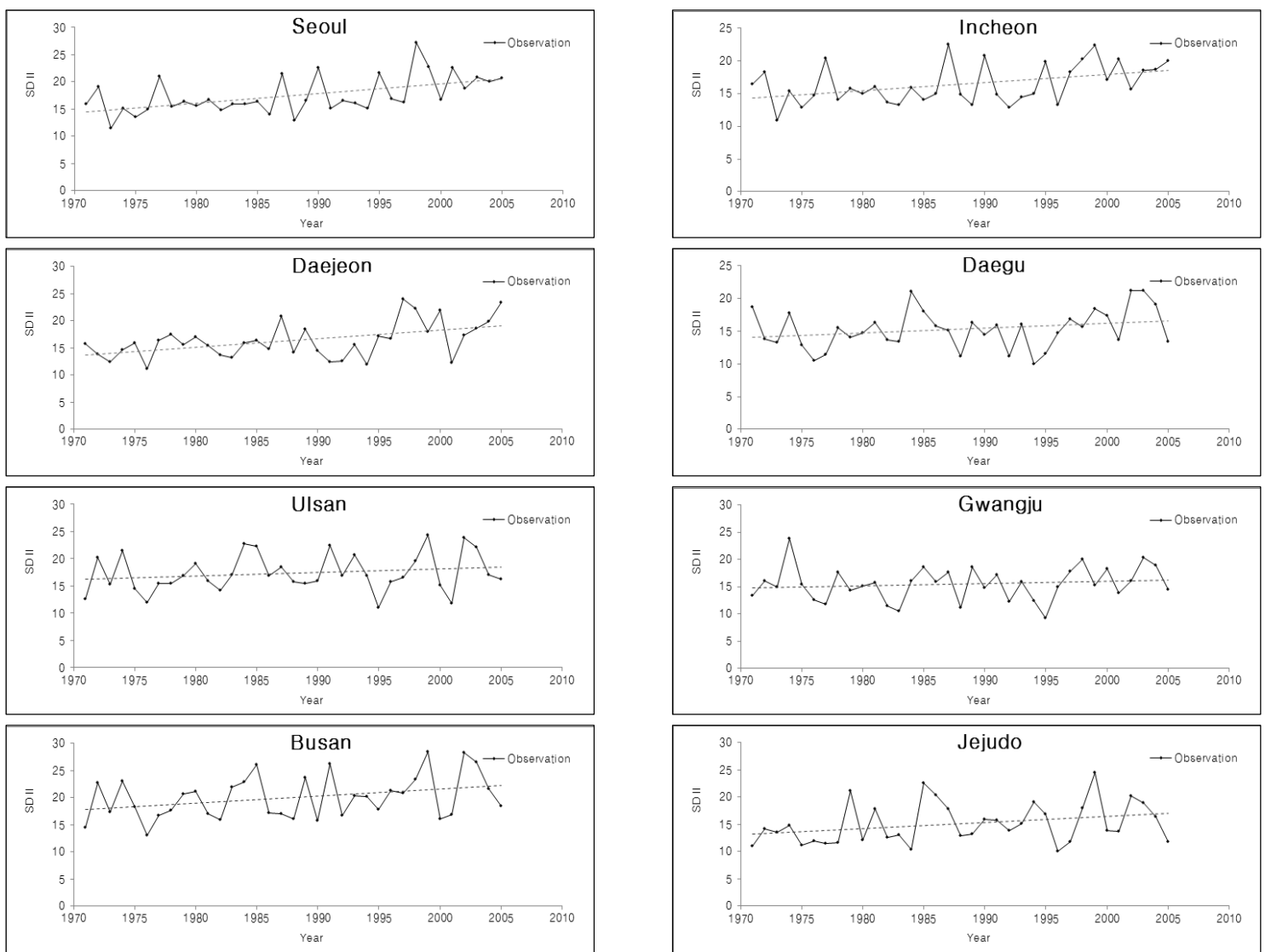

Fig. 5. Rainfall intensity (Simple daily intensity index, $S D \Pi$ ) 

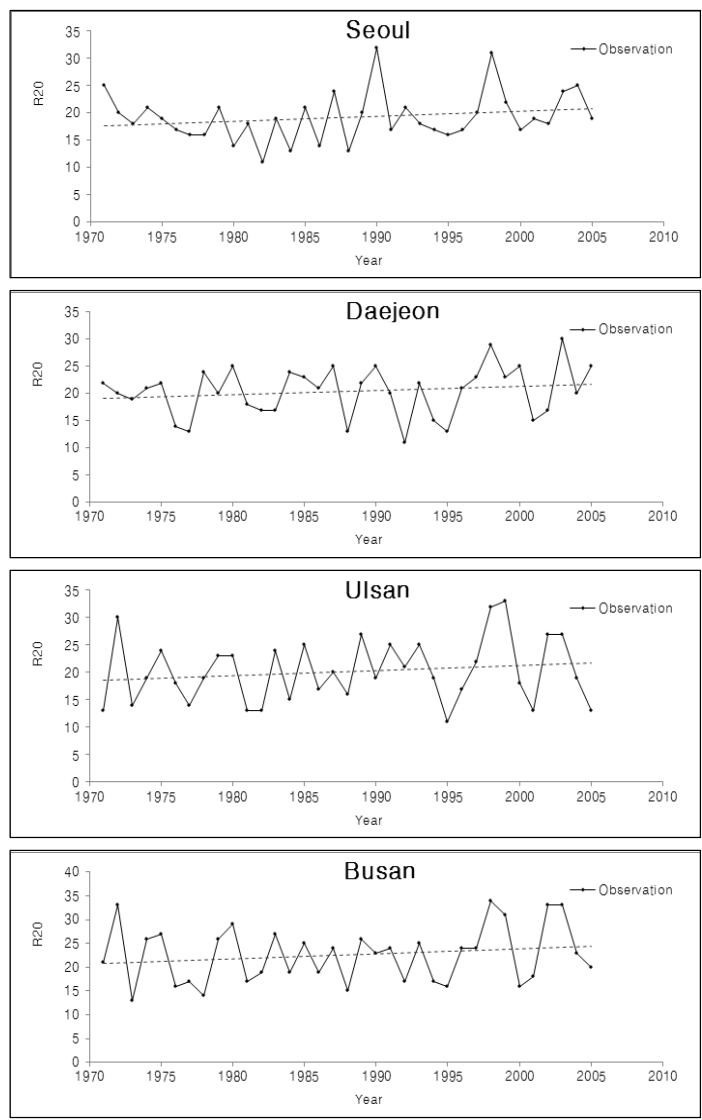
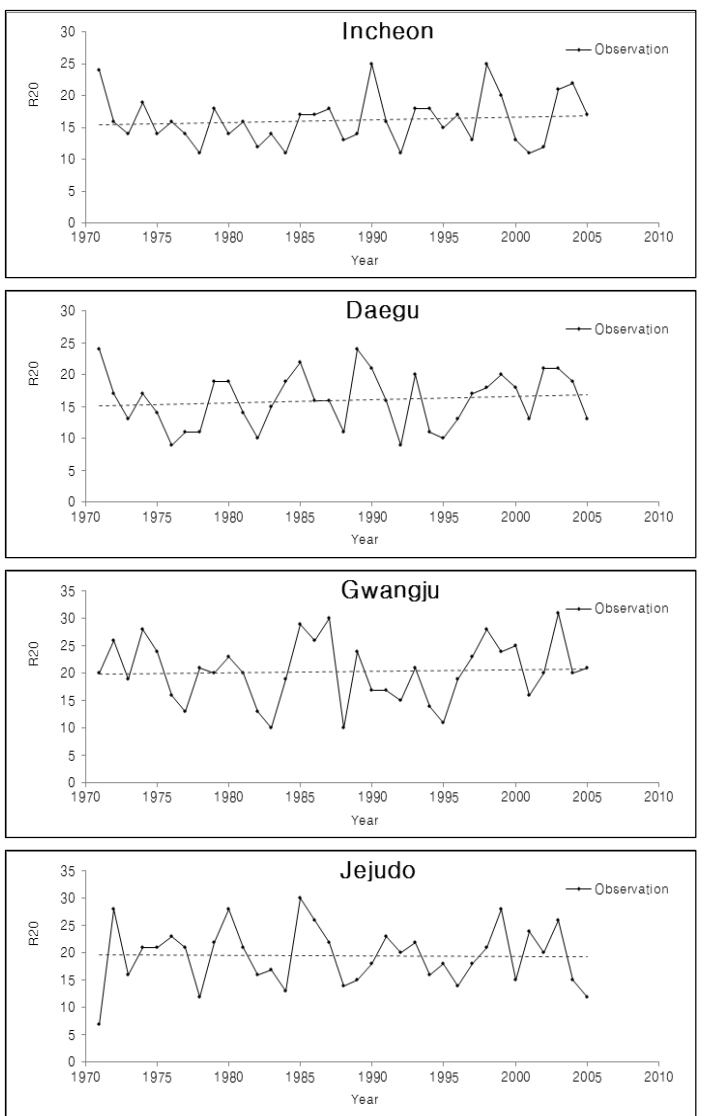

Fig. 6. The number of heavy precipitation days $(R 20)$
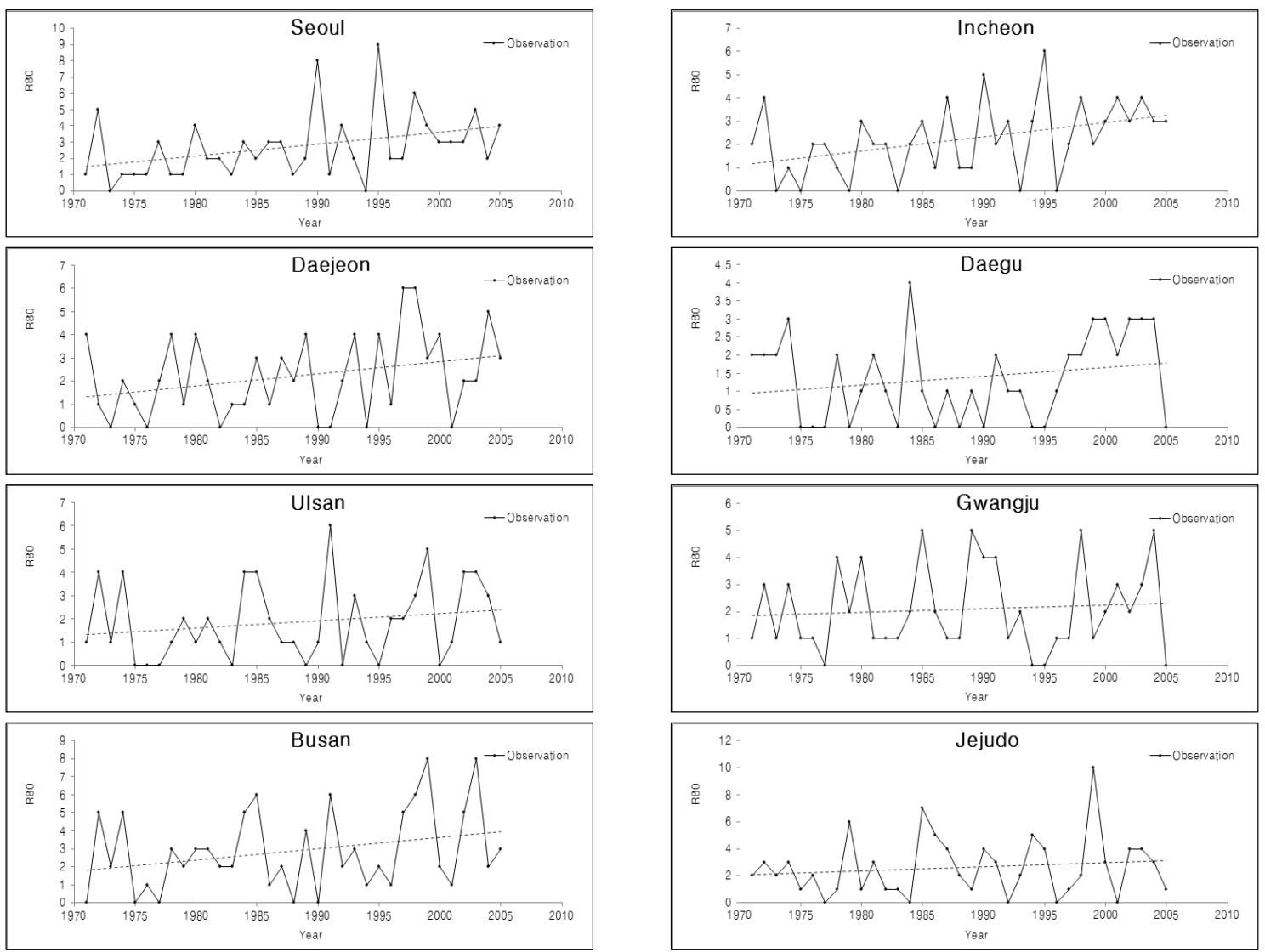

Fig. 7. The number of heavy precipitation days $(R 80)$ 

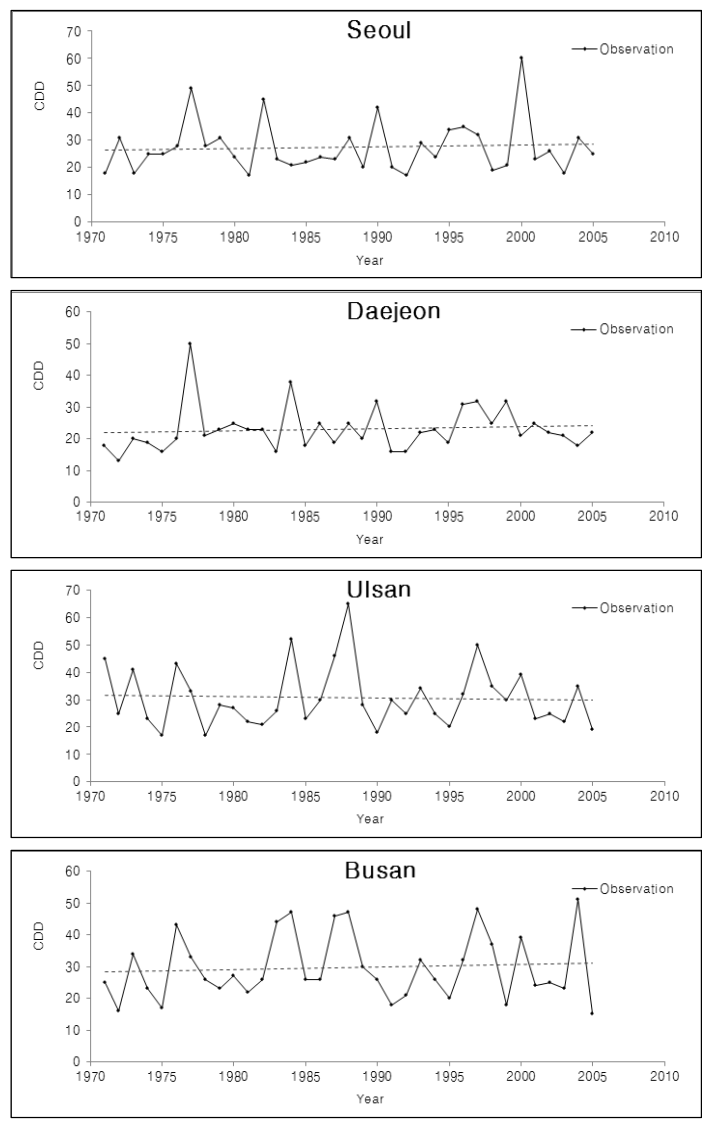

Fig. 8. Consecutive dry days $(C D D)$
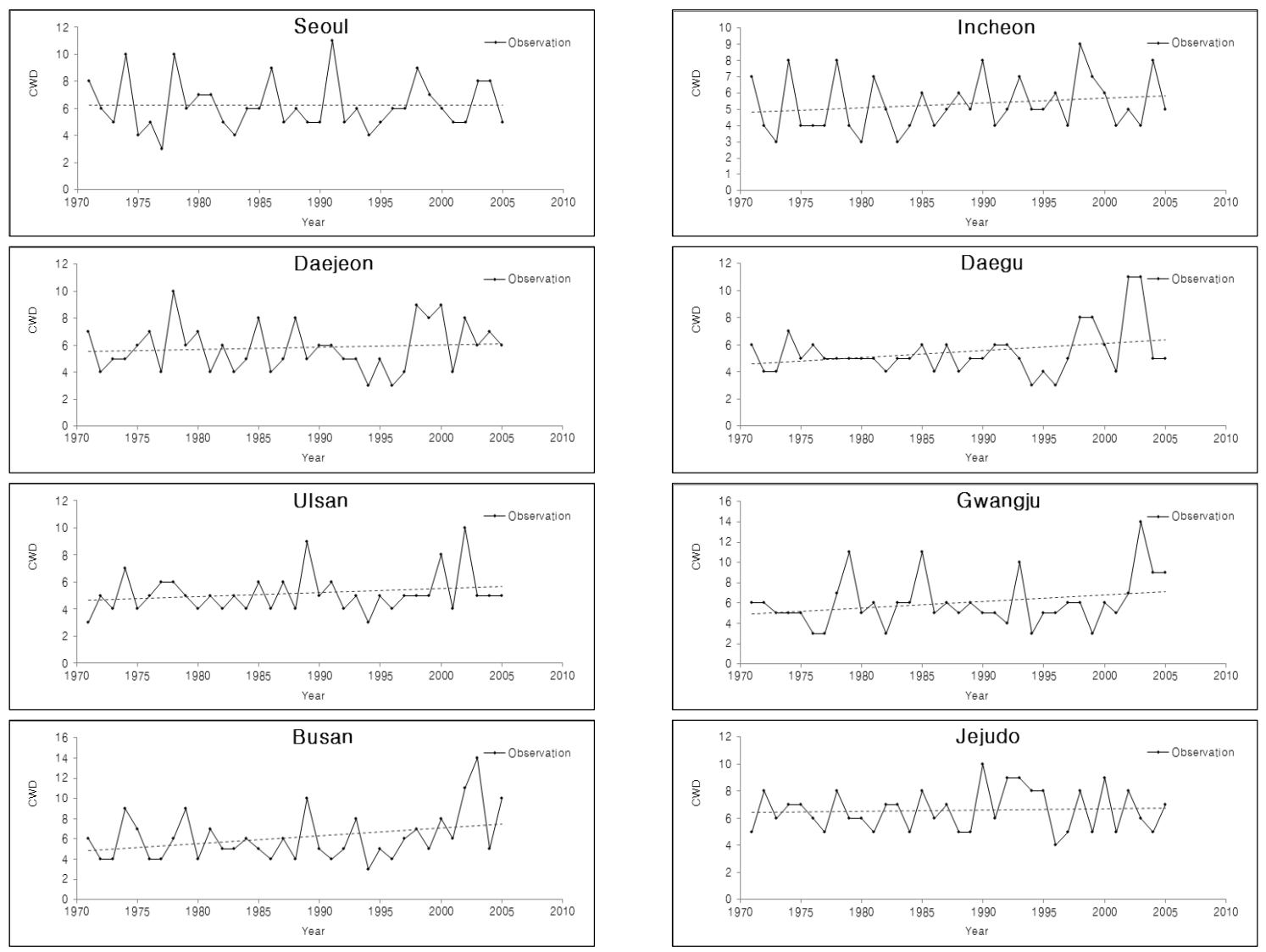

Fig. 9. Consecutive Wet days $(C W D)$ 


\section{4 관측 및 기후모의자료에 대한 빈도해석}

본 연구에서는 빈도해석에 따른 확률분포형으로는 Gumbel분포를 채택하였다. 국토해양부에서 제시한 확률 강우량도 개선 및 보안연구를 살펴보면 관측소별 최적 분포형을 Gumbel분포로 채택한 바 있다. 이에 본 연구 에서도 모든 관측소에 대하여 Gumbel 분포를 채택하는 것이 타당할 것으로 판단된다. 매개변수 추정방안으로 확률가중모멘트법을 사용하였다. 유역의 강우 양상을 일 관되게 반영하고, 정상적인 형태의 확률강우량을 산정하 기 위하여 동일한 확률분포형과 매개변수 추정법을 사 용하였다.
지점 빈도해석시 기후변화 시나리오자료의 경우 이상 치 및 편의를 제거한 보정된 자료를 적용하여 빈도해석 을 실시하였다. 시나리오별 빈도별 증가율을 Target I 을 기준으로 산정한 결과를 보면 RCP 4.5 시나리오에서는 최고 $30 \%$ 까지 증가함을 알 수 있었으며, RCP 8.5 시나 리오에서는 Target II 기간에 대해서는 소폭 증가하는 경 향을 나타나다가, 미래에는 최대 $45 \%$ 까지 증가하는 것 으로 나타났다. 아래의 Table 5 Table 7및 Fig. 10 Fig. 11 에서 제시하고 있는 결과를 보면, 우리나라의 인천, 대전, 광주, 부산 등에서는 확률강수량이 현재보다 증가 하는 것을 볼 수 있으며, 서울, 대구, 울산 등 일부지역 에서는 다른 지역에 비하여 소폭으로 증가하는 것으로 판단된다.

Table 5. Probability of precipitation by Frequency (Target $\mid: 1971 \sim 2005$ )

\begin{tabular}{c|c|c|c|c|c|c|c}
\hline \multirow{2}{*}{ No. } & \multirow{2}{*}{ Station } & \multicolumn{3}{|c|}{$\begin{array}{c}\text { frequency based precipitation } \\
\text { (Observation, } m m / d a y)\end{array}$} & \multicolumn{3}{c}{$\begin{array}{c}\text { frequency based precipitation } \\
\text { (Reference, } m \text { m } / \text { day })\end{array}$} \\
\cline { 3 - 8 } & & $80 \mathrm{yrs}$ & $100 \mathrm{yrs}$ & $200 \mathrm{yrs}$ & $80 \mathrm{yrs}$ & $100 \mathrm{yrs}$ & $200 \mathrm{yrs}$ \\
\hline \hline 108 & Seoul & 362.9 & 375.0 & 412.5 & 386.0 & 399.7 & 442.2 \\
\hline 112 & Incheon & 337.6 & 349.4 & 386.2 & 280.6 & 289.9 & 318.5 \\
\hline 133 & Daejeon & 286.8 & 295.9 & 324.4 & 296.0 & 305.8 & 336.1 \\
\hline 143 & Daegu & 230.0 & 237.6 & 261.2 & 273.7 & 283.7 & 314.5 \\
\hline 152 & Ulsan & 305.1 & 315.4 & 347.2 & 279.7 & 288.7 & 316.5 \\
\hline 156 & Gwangju & 271.9 & 280.3 & 306.6 & 288.3 & 297.7 & 326.7 \\
\hline
\end{tabular}

Table 6. Increasing rate of precipitation in the future by RCP 4.5 Scenarios (\%)

\begin{tabular}{|c|c|c|c|c|c|c|c|c|c|c|}
\hline \multirow{3}{*}{ No. } & \multirow{3}{*}{ Station } & \multicolumn{9}{|c|}{ RCP 4.5} \\
\hline & & \multicolumn{3}{|c|}{$80 \mathrm{yrs}$} & \multicolumn{3}{|c|}{$100 \mathrm{yrs}$} & \multicolumn{3}{|c|}{$200 \mathrm{yrs}$} \\
\hline & & Target II & TargetIII & TargetIV & Target II & TargetIII & TargetIV & Target II & TargetIII & TargetIV \\
\hline 108 & Seoul & 5 & 5 & 10 & 5 & 5 & 10 & 5 & 5 & 10 \\
\hline 112 & Incheon & 20 & 25 & 25 & 20 & 25 & 25 & 20 & 30 & 25 \\
\hline 133 & Daejeon & 5 & 10 & 20 & 5 & 10 & 20 & 5 & 10 & 25 \\
\hline 143 & Daegu & 5 & 5 & 5 & 5 & 5 & 5 & 5 & 5 & 5 \\
\hline 152 & Ulsan & 20 & 5 & 5 & 20 & 5 & 5 & 20 & 5 & 5 \\
\hline 156 & Gwangju & 5 & 5 & 15 & 5 & 5 & 15 & 5 & 5 & 20 \\
\hline 159 & Busan & 10 & 10 & 20 & 10 & 10 & 20 & 10 & 10 & 20 \\
\hline
\end{tabular}


Duck Hwan Kim · Yon Soo Kim • Seung Jin Hong $\cdot$ Sidoeun Ly $\cdot$ Younghun Jung $\cdot$ Hung Soo Kim

Table 7. Increasing rate of precipitation in the future by RCP 8.5 Scenarios (\%)

\begin{tabular}{|c|c|c|c|c|c|c|c|c|c|c|}
\hline \multirow{3}{*}{ No. } & \multirow{3}{*}{ Station } & \multicolumn{9}{|c|}{ RCP 8.5} \\
\hline & & \multicolumn{3}{|c|}{$80 \mathrm{yrs}$} & \multicolumn{3}{|c|}{$100 \mathrm{yrs}$} & \multicolumn{3}{|c|}{$200 \mathrm{yrs}$} \\
\hline & & Target II & TargetIII & TargetIV & Target $\Pi$ & TargetIII & TargetIV & Target II & TargetIII & TargetIV \\
\hline 108 & Seoul & 5 & 5 & 5 & 5 & 5 & 5 & 5 & 5 & 5 \\
\hline 112 & Incheon & 5 & 5 & 40 & 5 & 5 & 40 & 5 & 5 & 45 \\
\hline 133 & Daejeon & 5 & 5 & 20 & 5 & 5 & 25 & 5 & 5 & 25 \\
\hline 143 & Daegu & 5 & 5 & 5 & 5 & 5 & 5 & 5 & 5 & 5 \\
\hline 152 & Ulsan & 5 & 15 & 5 & 5 & 15 & 5 & 5 & 15 & 5 \\
\hline 156 & Gwangju & 5 & 20 & 10 & 5 & 20 & 10 & 5 & 20 & 10 \\
\hline 159 & Busan & 5 & 20 & 30 & 5 & 20 & 30 & 5 & 20 & 35 \\
\hline
\end{tabular}
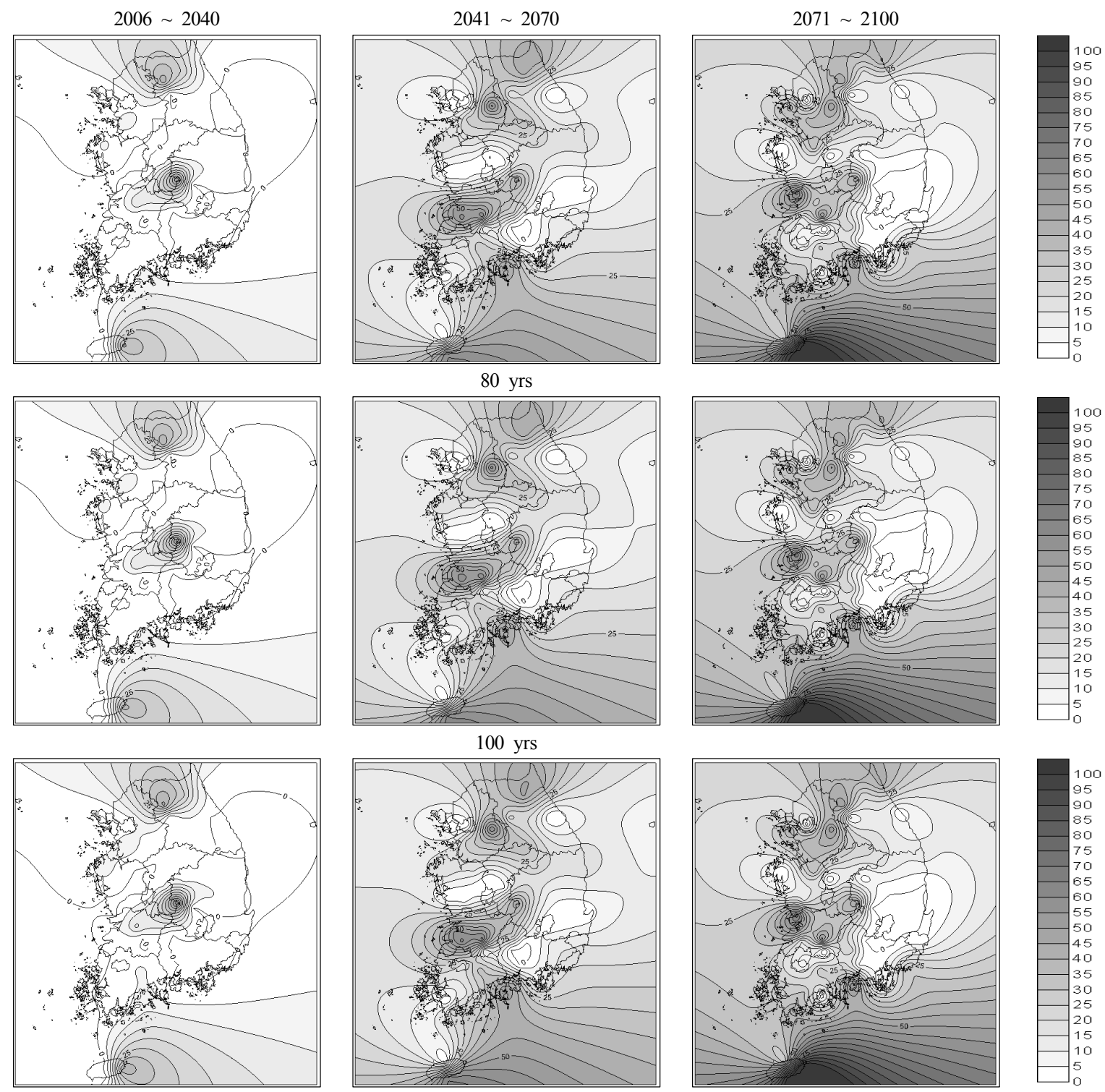

Fig. 10. Increasing rate of precipitation in the future by RCP 4.5 Scenarios 

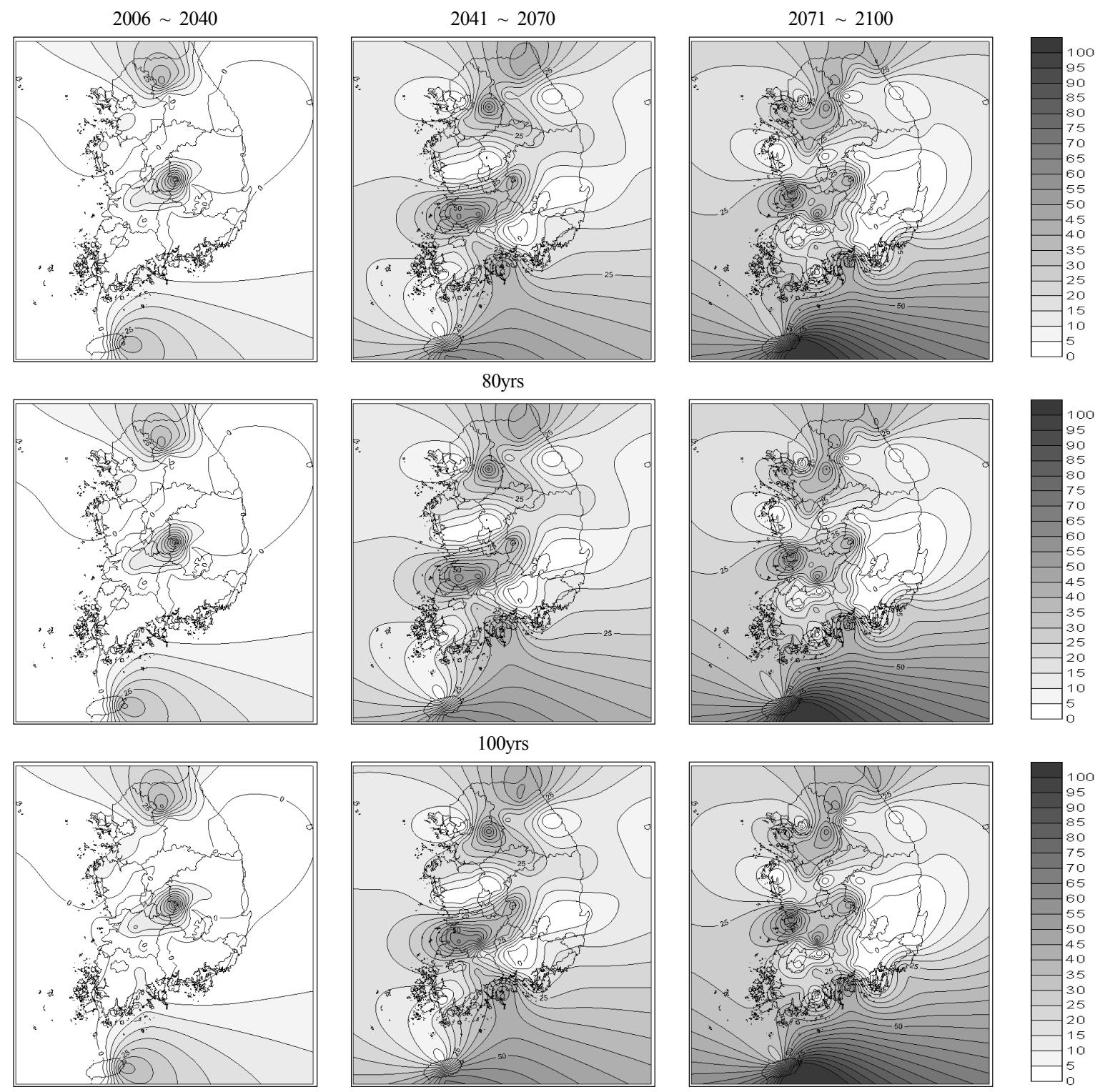

200yrs

Fig. 11. Increasing rate of precipitation in the future by RCP 8.5 Scenarios

\section{6. 결 론}

본 연구에서는 기상청에서 제공하는(HadGEM3-RA) 고해상도 대표농도경로(RCP) 시나리오를 이용하여 극치 통계분석과 지점 빈도해석을 기상청 관측소 58 개 지점 을 대상으로 실시하였다.

우리나라 주요도시를 대상으로 극치통계분석 결과 집 중호우를 의미하는 $R 80$ 의 경우 전 지점에서 증가하는 추세를 나타냈으며, 비가 온 날들의 강우강도인 $S D \Pi$ 는 증가하는 것으로 분석되었다. 비가 오지 않는 연속적 인 날을 나타내는 $C D D$ 는 대구와 울산을 제외한 전 지 점에서 증가하였으며, 비가 오는 습윤일의 연속일을 나 타내는 $C W D$ 는 모든 지점에서 증가하는 것으로 나타 나 한반도의 가뭄 및 집중호우 특성이 뚜렷해지고 있음
을 확인할 수 있었다. 미래 기후변화에 따라 이러한 수 문학적 특성은 증가할 것으로 판단되기에 이에 대한 대 책이 필요할 것으로 여겨진다.

지점 빈도해석시 Gumbel분포형을 선정하고, 확률가중 모멘트법을 이용하여 매개변수를 추정하였으며, 이상치 및 편의를 보정한 기후변화 시나리오 자료를 이용하여 미래 목표기간별 확률강수량을 산정하였다. 과거 관측 자료와 기후변화 시나리오를 고려한 미래 확률강수량을 산정하고, 이를 비교한 결과 미래에 해당하는 Target II (2006 2040), III(2041 2070), IV(2071 2100)에서 시나 리오별 목포기간별 확률강수량은 지속적으로 증가하는 것을 확인할 수 있었다. 시나리오별 빈도별 증가율을 보 면 RCP 4.5 시나리오는 최고 $30 \%$ 까지 증가하는 것으로 나타났으며, RCP 8.5 시나리오 Target II 기간에 대해서 
는 증가하는 경향을 나타나지 않다가, Target III 이후에

는 최대 $45 \%$ 까지 증가하는 것으로 나타났다.

이상의 연구를 통해 전 지구 기온 상승으로 목표기간 별 강수량이 증가함에 따라 확률강수량 또한 증가하는 것 으로 나타났으며, 이를 고려한 시설물에 대한 설계기준 및 기후변화에 대비가 필요할 것으로 판단된다. 본 연구 결과는 기후변화를 고려한 목표기간별 방재기준의 재설정 을 위한 기초자료로 활용될 수 있을 것으로 기대된다.

\section{감사의 글}

본 연구는 소방방재청 자연재해저감기술개발사업의 지 원으로 수행한 '기후변화를 고려한 시설별 방재기준 가이 드라인 개발, [NEMA-자연-2013-53]과제의 성과입니다.

\section{References}

Fowler, HJ, Ekström, M, Kilsby, CG and Jones, PD (2005). New estimates of future change in extreme rainfall across the UK using regional climate model integraiton: 1. Assessment of control climate, J. of Hydrology, 300(1-4), pp. 212-233.

Gabriele, V, Enrico, S and Silvio, G (2013). Projections of heavy rainfall over the central United States based on CMIP5 models, Royal Meteorological Society, 14, pp. 200-205

Hong, SJ, Kim, BS, Kim, HS and Kang, NR (2012). Analysis of regional water resources characteristics through applying the climate change variability index using by RCP 8.5 scenario, J. of KOSHAM, 13(11), pp. 704-710, [Korean Literature]

IPCC (2007). Climate Change 2007, the fourth assessment report (AR4) of the Intergovernmental panel on climate change.

IPCC (2013). Climate Change 2013, the fifth assessment report (AR5) of the Intergovernmental panel on climate change.

Kim, DH, Hong, SJ, Kim, BS and Kim, HS (2012). Impact assessment of climate change on urban drainage system based on IPCC AR5 RCP 8.5 climate change scenario, Journal of KOSHAM, 13(11), pp. 327-331. [Korean Literature]

Kim, BS, Kim, BK, Kyoung, MS and Kim, HS (2008). Impact assessment of climate change on extreme rainfall and I-D-F analysis, J. of Korea Water Resources Association, 41(5), pp. 129-141. [Korean Literature]

Kim, BS, Sung, JH, Lee, BH and Kim, DJ (2013).
Evaluation on the impact of extreme droughts in South Korea using the SPEI and RCP8.5 climate change scenario, Journal of KOSHAM, 13(2), pp. 97-109. [Korean Literature]

Kim, SJ (2011). Impact of climate change on water resources and ecological habit in a river basin, Doctor's Thesis, Inha University. [Korean Literature]

Kyoung, MS, Lee, JK and Kim, HS (2009). Downscaling technique of monthly GCM using daily precipitation generator, J. of Korea Society of Civil Engineers, 29(5), pp. 441-452. [Korean Literature]

Kyoung, MS (2010). Assesment of climate change effect on standardized precipitation index and frequency based precipitation, Doctor's Thesis, Inha University. [Korean Literature]

Lee, KH (2011). Estimation of expected flood damage considering uncertainty and under climate change, Doctor's Thesis, Inha University. [Korean Literature]

STARDEX (STAtistical and Regional dynamical Downscaling of Extremes for European regions) (2005).

http://www.cru.uea.ac.uk/projects/stardex/

Sung, JH, Kang, HS, Park, SH, Cho, CH, Bae, DH and Kim, YO (2012). Projection of extreme precipitation at the end of 21st century over South Korea based on representative concentration pathways (RCP), Atmosphere. Korean Meteorological Society, 22(2), pp. 221-231. [Korean Literature]

Tinsley Odena, J. and Prudhommeb, S. (2002). Estimation of modeling error in computational mechanics, $J$. of Computational Physics, 182(2), pp. 496- 515.

Vincent O. Otieno and Richard O. Anyah (2013). CMIP5 simulated climate conditions of the Greater Horn of Africa(GHA).Part I : contemporary climate, Climate Dynamics, 41(7-8), pp. 2081-2097.

Vincent O. Otieno and Richard O. Anyah (2013). CMIP5 simulated climate conditions of the Greater Horn of Africa(GHA).Part II: projected climate, Climate Dynamics, 41(7-8), pp. 2099-2113.

World Meteorological Organization (WMO) (2009). Guidelines on analysis of extremes in a changing climate in support of informed decisions for adaptation, Climate data and monitoring, WCDMP-No.72.

논문접수일 : 2013년 10월 29일 심사의뢰일 : 2013년 11월 06일 심사완료일 : 2013년 11월 27일 